\title{
Association of the paired box 2 gene polymorphism with the susceptibility and pathogenesis of Henoch-Schönlein purpura in children
}

\author{
JING CHEN $^{1}$, XIANGLING FANG $^{2}$, XIQIANG DANG ${ }^{2}$, XIAOCHUAN WU $^{2}$ and ZHUWEN YI ${ }^{2}$ \\ ${ }^{1}$ Department of Dermatology, The Third Xiangya Hospital, Central South University, Changsha, Hunan 410013; \\ ${ }^{2}$ Department of Paediatrics, The Second Xiangya Hospital, Central South University, Changsha, Hunan 410011, P.R. China
}

Received December 27, 2013; Accepted July 1, 2014

DOI: $10.3892 / \mathrm{mmr} .2014 .2908$

\begin{abstract}
The present study aimed to investigate the distribution of paired box 2 (PAX2) gene polymorphisms in healthy populations and in patients with Henoch-Schönlein purpura (HSP), focusing on the association between PAX2 gene polymorphisms and the susceptibility and clinical characteristics of HSP. Genomic DNA was extracted from the peripheral venous blood of 100 healthy children (mean age: $5 \pm 1.9$ years) and 118 children with HSP (mean age: 10.2 \pm 2.3 years). Polymerase chain reaction (PCR) was used to amplify exons 1-12 of the PAX2 gene. Denaturing high performance liquid chromatography and DNA sequencing analysis were conducted for screening of mutations in the PAX2 gene in the PCR products. No genetic polymorphism of the PAX2 gene was identified in exons 1-7, 9, 10 or 12 . Two single nucleotide polymorphisms (SNPs), which presented as complete linkage haplotype $798 \mathrm{C}>\mathrm{T} / 909 \mathrm{~A}>\mathrm{C}$, were identified in exon 8 . An SNP (1164T $>$ A) was also identified in exon 11. No significant difference in the allele and genotype frequency distribution of exon $8(798 \mathrm{C}>\mathrm{T})$ or $11(1164 \mathrm{~T}>\mathrm{A})$ of the PAX2 gene was identified between the HSP and control groups $(\mathrm{P}>0.05)$. However, the frequency of the PAX2 heterozygous genotype 798C $>\mathrm{T}$ in the HSP with nephritis (HSPN) group was significantly higher than those in the controls and in the HSP without nephritis group $(\mathrm{P}<0.05)$. Furthermore, no significant correlation was identified between the PAX2 gene exon 8 polymorphism (798 $\mathrm{C}>\mathrm{T}$ ) and the renal pathology of children with HSPN. An SNP (1164T $>A$ ) was identified in exon 11. The PAX2 heterozygous genotype $798 \mathrm{C}>\mathrm{T}$ did not increase susceptibility to HSP, however, it may be used clinically as a screening indicator for HSP in children with a high risk of renal involvement.
\end{abstract}

Correspondence to: Dr Zhuwen Yi, Department of Paediatrics, The Second Xiangya Hospital, Central South University, 139 Middle Renmin Road, Changsha, Hunan 410011, P.R China

E-mail: yizhuwenmedsci@163.com

Key words: Henoch-Schönlein purpura, nephritis, paired box 2, exon, denaturing high performance liquid chromatography, single nucleotide polymorphism

\section{Introduction}

Henoch-Schönlein purpura (HSP) is a small vessel vasculitis syndrome and is the most common vasculitis in children. The typical clinical features of HSP include non-thrombocytopenic purpura, joint pain, stomach pain, gastrointestinal bleeding and renal system dysfunction (1). In addition, HSP has also been rarely associated with the following clinical manifestations: Thrombosis, vomiting, adult human immunodeficiency virus infection, intestinal perforation, cerebral hemorrhage, intestinal lesions, neuropathy, ischemic stroke, cerebrovascular disease, skin rash, joint swelling and pulmonary hemorrhage (1-7). The kidneys are the most commonly affected organs in children with HSP and their involvement primarily causes morbidity and mortality (8).

Numerous studies have demonstrated the role of polymorphisms of various genes in the susceptibility, progression and prognosis of HSP and HSP with nephritis (HSPN). Variations in C1GALT1, CTLA-4 exon $1+49 \mathrm{~A} / \mathrm{G}$, interleukin (IL) 8 gene 2767 A/G, human leukocyte antigen (HLA)-A, HLA-B, mediterranean fever E148Q, tumor necrosis factor- $\alpha$ and polymorphisms at -2123 and -825 in the p-selectin gene have been reported to be associated with HSP and/or HSPN (9-15). However, several other genetic polymorphisms, including TLR-2 Arg753Gln, TLR-4 Asp299Gly, TLR-4 Thr399Ile, CD18 AvaII, toll-like receptor 4, IL-6 receptor, IL-6 signal transducer and the $-173 \mathrm{G} / \mathrm{C}$ polymorphism in the macrophage migration inhibitory factor gene are not associated (16-20).

Paired box 2 (PAX2) is an essential nuclear transcription factor in the development of the human embryonic kidney and its expression gradually decreases with the maturity of nephrons (21). Human PAX2 is located at 10q24-25, covering $\sim 70 \mathrm{~kb}$ of 12 exons (22). The PAX2 Mutation Database (http://www.hgu.mrc.ac.uk/Softdata/PAX2) has reported four single nucleotide polymorphisms (SNPs) within the PAX2 coding region, including $291 \mathrm{C}>\mathrm{T}$ at exon $3,798 \mathrm{C}>\mathrm{T}$ and $909 \mathrm{~A}>\mathrm{C}$ at exon 8 and $932 \mathrm{C}>\mathrm{T}$ at exon 9 . The nonsense mutation of $932 \mathrm{C}>\mathrm{T}$ causes the 331st amino acid Alanine to mutate to Valine, while the three other SNPs are all sense mutations.

Mutations in the PAX2 gene have been associated with renal developmental abnormalities, urinary tract complications and oncogenic processes (23). Increased apoptosis has been reported in the fetal kidneys of PAX $2^{1 \mathrm{Neu}}+/-$ mutant 
mice (24). In children, PAX2 and hepatocyte nuclear factor-1 $\beta$ were identified as the common cause of renal aplasia and hypodysplasia (25). An earlier study demonstrated the expression of PAX2 in the podocytes of renal glomeruli and tubular epithelial cells of children with HSPN, suggesting the potential involvement of PAX2 in the progression of HSPN (26). A study by Yi et al investigated the distribution of polymorphisms in the PAX2 gene and examined the development of renal pathology. The study concluded that the 410CT/1521AC PAX2 genotype improved the prognosis of HSPN (27).

However, the association between polymorphisms of various exons of the PAX2 gene and HSPN remain to be fully elucidated. Therefore, the present study aimed to analyze the polymorphism sites of the 12 exons of PAX2 and to investigate the association between various polymorphisms in the PAX2 gene and the susceptibility and clinical characteristics of HSP and/or HSPN.

\section{Subjects and methods}

Study population. The present study was conducted at the Second Xiangya Hospital of Central South University (Changsha, China). The study protocol was reviewed and approved by the Ethics Committee of The Second Xiangya Hospital of Central South University and parents of all the children involved provided written informed consent prior to surgery. Between June 2003 and February 2007, a total of 118 children with HSP were recruited from the Department of Paediatrics, The Second Xiangya Hospital of Central South University. The conditions of all cases were diagnosed as HSP rather than other systemic diseases, including thrombocytopenic purpura or systemic lupus erythematosus. In addition, 100 healthy children, with no history of HSP, were enrolled in the present study as controls.

After $>6$ months follow up, the subjects were divided into two groups (HSPN and HSP) based on the results of urinary sediment erythrocyte count and determination of urine protein concentration at $24 \mathrm{~h}$. An erythrocyte count $>500,000$ at $12 \mathrm{~h}$ and a protein concentration $>150 \mathrm{mg}$ at $24 \mathrm{~h}$ were regarded as positive for HSPN (28). For the HSPN group ( $\mathrm{n}=80$ ), the primary course of disease was between 1 day and 24 months (mean course: $1.7 \pm 4.2$ months). After a follow-up of 7-48 months until June 2007, the course of disease was 6-70 months (mean course: $18.5 \pm 14.7$ months). For the HSP (without nephritis) group $(n=38)$, the course of disease was 4-45 months (mean course: $9.2 \pm 10.3$ months). Renal needle biopsy was performed on 64 cases in the HSPN group. Based on the standards established by the International Study of Kidney Diseases in Children (29), the cases were classified as follows: Grade II $(n=12)$, grade III $(\mathrm{n}=43)$, grade IV $(\mathrm{n}=8)$ and grade $\mathrm{V}(\mathrm{n}=1)$.

DNA extraction. Fresh blood (5 $\mathrm{ml}$ in $2 \%$ ethylenediaminetetraacetic acid (Junrui Biotechnology Co., Ltd., Shanghai, China) was obtained from each subject. The genomic DNA was extracted from peripheral venous blood using a salting-out method (30)

Polymerase chain reaction (PCR) analysis. The sequences of exons 1-12 of PAX2 were amplified by PCR. The primers (Shanghai Bioengineering Co, Ltd., Shanghai, China) were designed within the region of each exon based on a previous study $(31,32)$ using Primer Premier 5.0 software (Premier
Biosoft International, Palo Alto, CA, USA). PCR was performed in a $25 \mu 1$ reaction volume containing $50 \mathrm{ng} / \mathrm{ml}$ genomic DNA, 2.5 $\mu 1$ 10X PCR buffer (containing $1.5 \mathrm{mM}$ magnesium chloride), $2 \mu \mathrm{l} 500 \mu \mathrm{M}$ deoxyribonucleotides, $1 \mu \mathrm{l}$ $5 \mu \mathrm{M}$ primer and $0.25 \mu 15 \mathrm{U} / \mu \mathrm{l}$ Taq DNA polymerase (MBI Fermentas, Vilnius, Lithuania). Amplification was performed under the following conditions: Sequencing thermal cycling parameters included $96^{\circ} \mathrm{C}$ for 3 min and 39 cycles of $96^{\circ} \mathrm{C}$ for $45 \mathrm{sec}$, appropriate annealing temperature for the particular primer pair for $1 \mathrm{~min}$ (Table I), $72^{\circ} \mathrm{C}$ for $1 \mathrm{~min}$ and final extension at $72^{\circ} \mathrm{C}$ for $10 \mathrm{~min}$ using the PCR System EDC-810 (Eastwin Life Science Inc., Beijing, China). The PCR products $(\sim 5 \mu \mathrm{l})$ were then subjected to $1.5 \%$ agarose gel electrophoresis.

Denatured high performance liquid chromatography (DHPLC). The PCR product $(4 \mu \mathrm{l})$ was mixed with the same volume of known wild-type sample. The mixture was denatured at $95^{\circ} \mathrm{C}$ for $3 \mathrm{~min}$, and the temperature was then decreased by $1^{\circ} \mathrm{C}$ per second until it reached $45^{\circ} \mathrm{C}$, in order to form a mixture of heterogeneous and homologous double-stranded DNA. The mixture was then separated using a WAVE DNA Fragment Analysis System (Transgenomic Inc., Santa Clara, CA, USA) with a linear acetonitrile gradient elution, consisting of buffer A ( $0.1 \mathrm{M}$ triethylamine acetate; TEAA) and buffer B (0.1 M TEAA in 25\% acetonitrile) at a constant flow rate of $0.9 \mathrm{ml} / \mathrm{min}$. The optimal temperature for the DNA fragment was provided by the software WaveMaker 4.0 (Transgenomic Inc.). The mutation type was determined by the elution peaks.

DNA sequence analysis. The PCR products demonstrating abnormal peaks and sections of products with normal peaks were sequenced using a 3730xl DNA Analyzer (Applied Biosystems, Foster City, CA, USA) for determination of the PAX2 genotypes.

Statistical analysis. All statistical analyses were performed using SPSS version 10.0 (SPSS, Inc., Chicago, IL, USA). The allelic and genotype frequencies of the PAX2 gene polymorphisms in the two groups were calculated, and reached genetic equilibrium using the Hardy-Weinberg law $(\mathrm{p} 2+2 \mathrm{pq}+\mathrm{q} 2)$, indicating that each group consisted of an independent population. The data are expressed as the mean \pm standard deviation. To determine the extent to which the subjects in the present study fit within the Hardy-Weinberg law, an allele or genotype comparison between the two groups and linkage disequilibrium analysis were conducted using a $\chi^{2}$ test or Fisher's analysis, respectively. $\mathrm{P}<0.05$ was considered to indicate a statistically significant difference.

\section{Results}

Demographic characteristics. Of the 118 children with HSP and HSPN, 76 patients were male with a mean age of $9.8 \pm 1.9$ years and 42 were female with a mean age of $10.6 \pm 2.2$ years. Among the 100 healthy children, 58 were male with a mean age of $9.5 \pm 2.0$ years and 42 were female with a mean age of $9.5 \pm 1.9$ years. The demographic characteristics of subjects in the three groups (including controls) are listed in Table II.

DHPLC screening of the PAX2 gene and DNA sequencing. The DHPLC profiles of all subjects revealed exons 1-7, 9, 10 and 12 with a single peak, while exons 8 and 11 had a distinct profile 
Table I. Sequences and annealing temperatures for the primers of the paired box 2 gene.

\begin{tabular}{|c|c|c|c|}
\hline Exon & Primer sequence (5'-3') & Product length (bp) & $\begin{array}{c}\text { Annealing } \\
\text { temperature }\left({ }^{\circ} \mathrm{C}\right)\end{array}$ \\
\hline \multirow[t]{2}{*}{1} & F: GTTCACТCATCCТCССТСССССАСC & & \\
\hline & R: GGAGCCGGGCGCGGGTACTC & 179 & 62.0 \\
\hline \multirow[t]{2}{*}{2} & F: CTGTGTGTGGGGTGTTGTGTT & & \\
\hline & R: AAGGCGTCTCTCCCGGGACAGCTGC & 246 & 61.8 \\
\hline \multirow[t]{2}{*}{3} & F: TGACCGGCTTTCCCGGCGCA & & \\
\hline & R: GAGGAAGCTGGAGTCCAGCC & 259 & 62.0 \\
\hline \multirow[t]{2}{*}{4} & F: CGGAATAGGAGTGGCATTTGA & & \\
\hline & R: CTCTAGGTGGGATCTGGTTT & 182 & 60.0 \\
\hline \multirow[t]{2}{*}{5} & F: TGATGCCATTTCCTCCTTCC & & \\
\hline & R: GCCACACCTCTTCCCTCCT & 175 & 61.0 \\
\hline \multirow[t]{2}{*}{6} & F: TCTCAGTGTTTGTCTGTCTC & & \\
\hline & R: TGAATGTTCTCTAACCGCCA & 175 & 59.0 \\
\hline \multirow[t]{2}{*}{7} & F: ACGCCCCGAGTGTCCATGT & & \\
\hline & R: CTGCCGGCTCCTTTCTACT & 250 & 58.8 \\
\hline \multirow[t]{2}{*}{8} & F: CCTTTCTCTGTGCGTGCATCAATAGA & & \\
\hline & R: GGCACCCTCCACTGAACGCAG & 231 & 59.0 \\
\hline \multirow[t]{2}{*}{9} & F: CCCTTCCCCTTTGTGTTTTT & & \\
\hline & R: AGGCAGCTGCAGCATTGTC & 151 & 60.0 \\
\hline \multirow[t]{2}{*}{10} & F: CCCCTCCCTGCAAACCAC & & \\
\hline & R: CGCTGTGAGGGCCATGAC & 150 & 61.5 \\
\hline \multirow[t]{2}{*}{11} & F: GCAGGCGTCACATCCCCACTC & & \\
\hline & R: CCGGCCACCAGGTGGCGTA & 148 & 62.5 \\
\hline \multirow[t]{2}{*}{12} & F: TGTTTGTCCTCTGACCCAGC & & \\
\hline & R: CAGACGGGGACGATGTGGA & 187 & 59.0 \\
\hline
\end{tabular}

F, forward; R, reverse.

Table II. Demographic characteristics of subjects enrolled.

\begin{tabular}{lcccc}
\hline & HSP & HSPN & Control & \\
Variable & $\mathrm{n},(\%)$ & $\mathrm{n},(\%)$ & $\mathrm{n},(\%)$ & \\
$\mathrm{n}=38$ & $\mathrm{n}=80$ & $\mathrm{n}=100$ & P-value \\
\hline Gender & & & & \\
Male & $22(57.89)$ & $54(67.50)$ & $58(58.00)$ & 0.379 \\
Female & $16(42.11)$ & $26(32.50)$ & $42(42.00)$ & \\
Age & $10.18 \pm 2.84^{\mathrm{a}}$ & $9.97 \pm 1.58^{\mathrm{a}}$ & $9.46 \pm 1.92^{\mathrm{a}}$ & 0.472 \\
\hline
\end{tabular}

${ }^{\mathrm{a}}$ Mean \pm standard deviation. HSP, Henoch-Schönlein purpura; HSPN, Henoch-Schönlein purpura with nephritis.

with multiple peaks (one single-peak and one double-peak). The products with abnormal DHPLC elution curves were sequenced and products with normal DHPLC elution curves were randomly selected as references. The DNA sequence results of exons 1-7, 9, 10 and 12 and the single-peaked products of exons 8 and 11 were identical to those published in GenBank (http://www.ncbi. nlm.nih.gov/nuccore/NM_003988.3). The results identified the
Table III. Distribution of the paired box 2 alleles and linkage disequilibrium in healthy children.

Actual (expected) value of allele compound

\begin{tabular}{ccc}
\cline { 2 - 3 } Allele & $909 \mathrm{~A}$ & $909 \mathrm{C}$ \\
\hline $798 \mathrm{C}$ & $186(173.0)$ & $0(13.0)$ \\
$798 \mathrm{~T}$ & $0(13.0)$ & $14(1.0)$ \\
& $\chi^{2}=200$ & $\mathrm{P}<0.001$ \\
& $\gamma=1$ & $\Delta=0.065$
\end{tabular}

presence of two SNPs in exon 8 (798C $>$ T and 909A $>$ C; Fig. 1) and one SNP in exon 11 (1164T>A) of the PAX2 gene (Fig. 2).

Linkage disequilibrium of $798 C>T$ and $909 A>C$ in exon 8 . Two PAX2 gene alleles, 798C $>\mathrm{T}$ and 909A $>\mathrm{C}$, were not randomly distributed. In the 218 subjects, $798 \mathrm{C}>\mathrm{T}$ was always present with 909A $>$ C. The correlation coefficient of polymorphism combination was $1(\gamma=1)$, the actual frequency of haplotype 798C/909A was 0.93 and the linkage equilibrium 

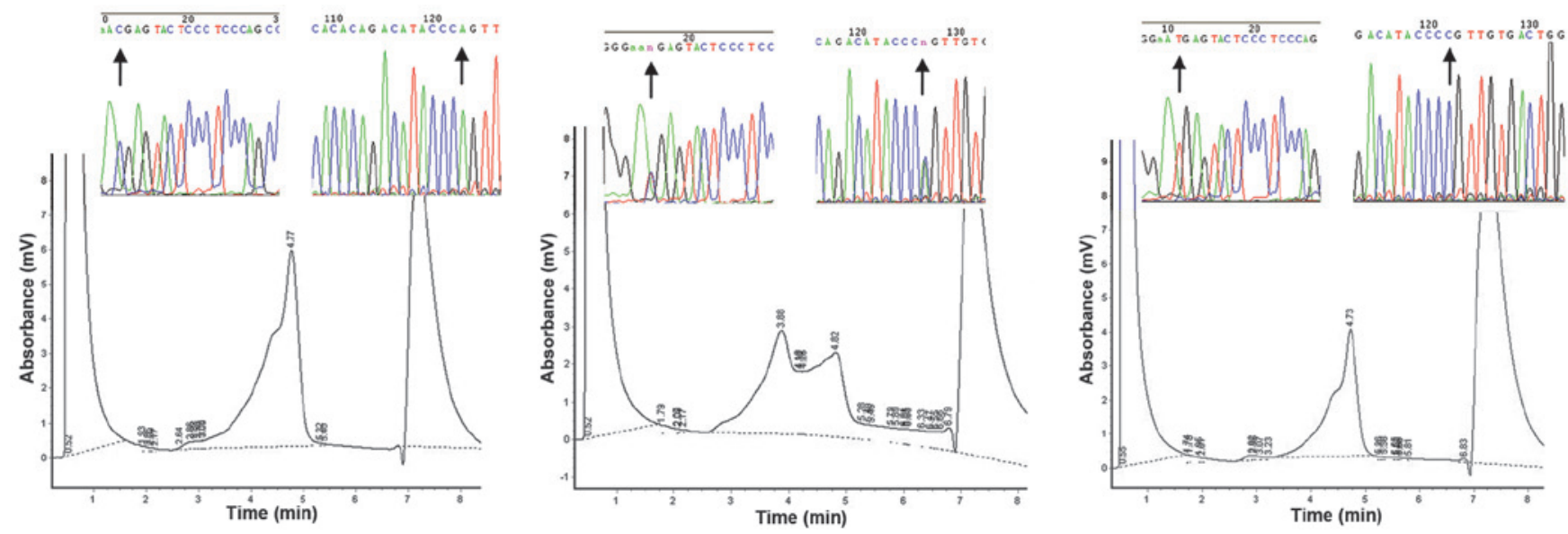

Figure 1. DNA sequencing for polymerase chain reaction product of the paired box 2 gene in exon 8 . Two single nucleotide polymorphisms were identified in exon 8: 798C $>$ T and 909A $>$ C. (A) Wild type (798 CC/909 AA). (B) Heterozygous mutant (798C $>\mathrm{T} / 909 \mathrm{~A}>\mathrm{C}$ ). (C) Homozygous mutant (798 TT/909 CC).

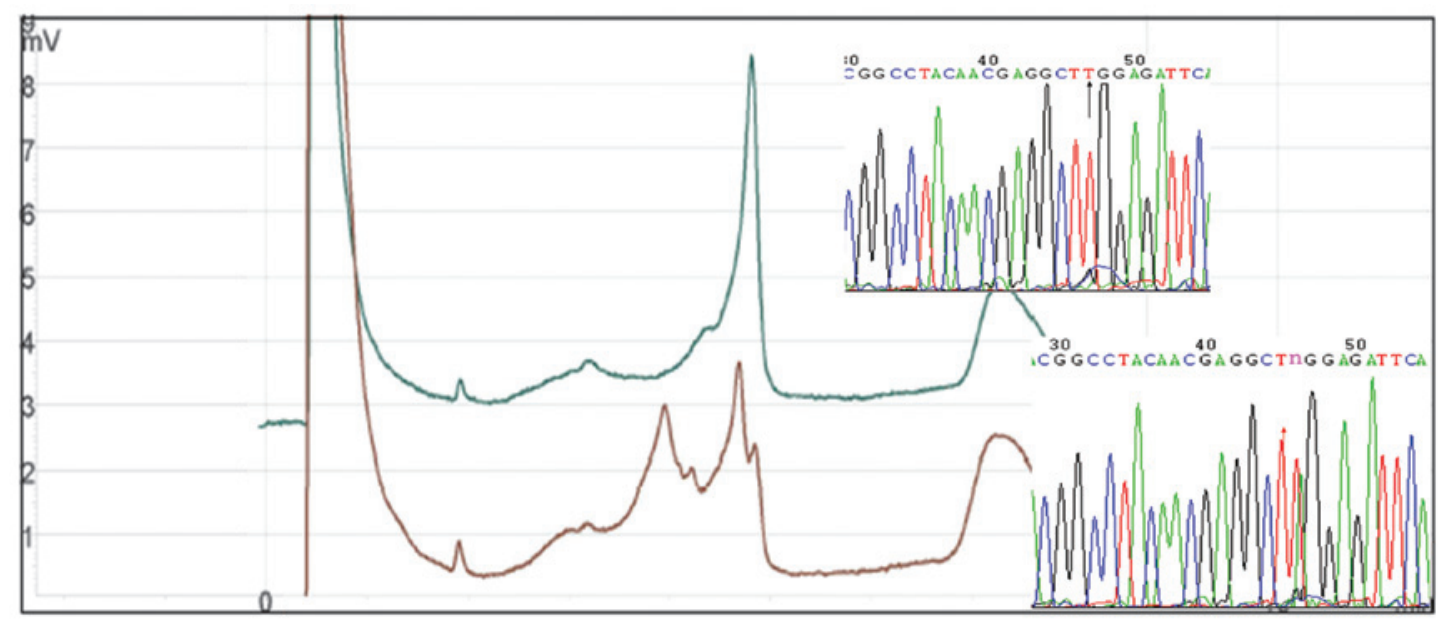

Figure 2. DNA sequencing for polymerase chain reaction product of the PAX2 gene in exon 11. A single nucleotide polymorphism (1164 T>A) was identified in exon 11 of the PAX2 gene. PAX2, paired box 2.

drift was $\Delta=0.065$. The difference was significant as evaluated by the $\chi^{2}$ test, indicating the complete linkage disequilibrium between 798C $>\mathrm{T}$ and 909A $>\mathrm{C}$ polymorphisms (Table III).

PAX2 gene exon 8 and 11 allele and genotype frequency distribution in normal controls and HSP patients. Due to the complete linkage disequilibrium between $798 \mathrm{C}>\mathrm{T}$ and 909A $>$ C polymorphisms, 798C $>\mathrm{T}$ was selected on behalf of the polymorphism of exon 8 . No significant difference in the allele and genotype frequency distribution of the PAX2 gene exon $8(798 \mathrm{C}>\mathrm{T})$ or $11(1164 \mathrm{~T}>\mathrm{A})$ was identified between the HSP and the control groups $(\mathrm{P}>0.05$; Table IV).

Allele and genotype frequency distribution of the PAX2 gene exon 8 and 11 in normal controls, HSP and HSPN patients. Based on the results of the urinary sediment erythrocyte count and $24 \mathrm{~h}$ urine protein determination, the HSP group was further divided into HSP without nephritis (HSP, $n=38)$ and HSP with nephritis (HSPN, $n=80$ ). The genotype frequency of exon $8798 \mathrm{C}>\mathrm{T}$ in the HSPN group $(20 / 80,25 \%)$ was higher when compared with the HSP $(3 / 38,7.89 \%)$ group and the control $(12 / 100,12 \%)$ group $(\mathrm{P}<0.05)$. However, no significant difference was identified in the genotype frequency of exon 8 $798 \mathrm{C}>\mathrm{T}$ between the HSP group and the control group $(\mathrm{P}>0.05$; Table V). In addition, no significant difference was identified in the allele and genotype frequency of exon 8 and 11, with the exception of 798C $>\mathrm{T}$ for exon 8 , among controls, HSP and HSPN patients $(\mathrm{P}>0.05$; Table V $)$.

Correlation between the PAX2 gene polymorphism (exon 8 $798 C>T)$ and the clinical characteristics of children with HSP. The correlation between various clinical features (gender, age, skin purpura, joint involvement, gastrointestinal symptoms and kidney lesions) of the 118 children with HSP and the frequency distribution of the PAX2 gene polymorphism exon 8 798C $>$ T were analyzed. No significant differences were observed in the features compared with the controls $(\mathrm{P}>0.05)$, with the exception of kidney lesions $(\mathrm{P}<0.05$; Table $\mathrm{VI})$.

Correlation between the PAX2 gene polymorphism (exon 8 $798 C>T$ ) and pathological lesions of children with HSPN. Compared with the overall genotype frequency $(20 / 80,25 \%)$ of exon $8798 \mathrm{C}>\mathrm{T}$ in the HSPN group, the children with HSP and genotype $798 \mathrm{C}>\mathrm{T}$ were more susceptible to nephrotic 
Table IV. Paired box 2 gene exon 8 and 11 alleles, genotype frequency (\%) and distribution in healthy controls and HSP patients.

\begin{tabular}{|c|c|c|c|c|c|}
\hline Exon & Genotype or allele & $\operatorname{HSP}(\mathrm{n}=118)(\%)$ & Control $(n=100)(\%)$ & $\chi^{2}$ & P-value \\
\hline \multicolumn{6}{|c|}{ Exon 8} \\
\hline \multicolumn{6}{|c|}{$798 \mathrm{C}>\mathrm{T}$} \\
\hline & $\mathrm{CC}$ & $94(79.66)$ & $87(87.00)$ & 2.257 & 0.324 \\
\hline & $\mathrm{CT}$ & $23(19.49)$ & $12(12.00)$ & & \\
\hline & $\mathrm{TT}$ & $1(0.85)$ & $1(1.00)$ & & \\
\hline & $\mathrm{C}$ & $211(89.41)$ & $186(93.00)$ & 2.506 & 0.113 \\
\hline & $\mathrm{T}$ & 25 (10.59) & $14(7.00)$ & & \\
\hline \multirow{2}{*}{\multicolumn{6}{|c|}{$\begin{array}{l}\text { Exon } 11 \\
1164 \mathrm{~T}>\mathrm{A}\end{array}$}} \\
\hline & & & & & \\
\hline & TT & $116(98.31)$ & $99(99.00)$ & 0.193 & 0.661 \\
\hline & $\mathrm{TA}$ & $2(1.69)$ & $1(1.00)$ & & \\
\hline & $\mathrm{AA}$ & $0(0.00)$ & $0(0.00)$ & & \\
\hline & $\mathrm{T}$ & $234(99.15)$ & $199(99.50)$ & 0.091 & 0.662 \\
\hline & A & $2(0.85)$ & $1(0.50)$ & & \\
\hline
\end{tabular}

HSP, Henoch-Schönlein purpura.

Table V. Paired box 2 exon 8 and 11 alleles, genotype frequency (\%) and distribution in normal controls, HSP patients without nephritis and HSP patients with nephritis (HSPN).

\begin{tabular}{|c|c|c|c|c|c|c|}
\hline \multirow[b]{2}{*}{ Exon } & \multirow[b]{2}{*}{$\begin{array}{l}\text { Genotype or } \\
\text { allele }\end{array}$} & \multicolumn{3}{|c|}{ Group } & \multirow[b]{2}{*}{$\chi^{2}$} & \multirow[b]{2}{*}{ P-value } \\
\hline & & $\begin{array}{l}\text { HSP without nephritis } \\
\qquad(\mathrm{n}=38)(\%)\end{array}$ & $\begin{array}{c}\text { HSPN } \\
(n=80)(\%)\end{array}$ & $\begin{array}{c}\text { Control } \\
(\mathrm{n}=100)(\%)\end{array}$ & & \\
\hline \multirow{2}{*}{\multicolumn{7}{|c|}{$\begin{array}{l}\text { Exon } 8 \\
798 \mathrm{C}>\mathrm{T}\end{array}$}} \\
\hline & & & & & & \\
\hline & $\mathrm{CC}$ & 34 (89.47) & $60(75.00)$ & 87 (87.00) & & \\
\hline & $\mathrm{CT}$ & $3(7.89)^{\mathrm{a}}$ & $20(25.00)$ & $12(12.00)^{\mathrm{a}}$ & & \\
\hline & $\mathrm{TT}$ & $1(2.63)$ & $0(0.00)$ & $1(1.00)$ & & \\
\hline & $\mathrm{C}$ & 71 (93.42) & $140(87.50)$ & $186(93.00)$ & 3.934 & 0.140 \\
\hline & $\mathrm{T}$ & $5(6.58)$ & $20(12.50)$ & $14(7.00)$ & & \\
\hline \multirow{2}{*}{\multicolumn{7}{|c|}{$\begin{array}{l}\text { Exon } 11 \\
1164 \mathrm{~T}>\mathrm{A}\end{array}$}} \\
\hline & & & & & & \\
\hline & $\mathrm{TT}$ & $38(100.00)$ & $78(97.50)$ & 99 (99.00) & 1.379 & 0.502 \\
\hline & TA & $0(0.00)$ & $2(2.50)$ & $1(1.00)$ & & \\
\hline & AA & $0(0.00)$ & $0(0.00)$ & $0(0.00)$ & & \\
\hline & $\mathrm{T}$ & $76(100.00)$ & $158(98.80)$ & 199 (99.50) & 1.369 & 0.504 \\
\hline & A & $0(0.00)$ & $2(1.20)$ & $1(0.50)$ & & \\
\hline
\end{tabular}

${ }^{a} \mathrm{P}<0.05$, vs. HSPN group. HSP, Henoch-Schönlein purpura; HSPN, Henoch-Schönlein purpura with nephritis.

syndrome $(41.67 \%)$ and proteinuria $(41.18 \%)$ and were less susceptible to hypertension (18.92\%), however, the difference was not statistically significant (all P>0.05; Table VII).

\section{Discussion}

The present study involved the analysis of PAX2 gene polymorphisms in children with HSP and in gender and age-matched healthy children in Hunan Province using DHPLC. The polymorphism sites of the 12 exons of PAX2 were identified and the association between various polymorphisms in the PAX2 gene and the susceptibility and clinical characteristics of HSP and/or HSPN were investigated. The results of the present study may be clinically significant for the determination of the susceptibility towards the development of kidney lesions in children with HSP. 
Table VI. Correlation between the paired box 2 gene polymorphism exon $8798 \mathrm{C}>\mathrm{T}$ and the clinical characteristics of children with HSP.

\begin{tabular}{|c|c|c|c|c|c|c|c|c|c|}
\hline \multirow[b]{3}{*}{ Organ damage } & \multirow[b]{3}{*}{ Number, $\mathrm{n}$} & \multicolumn{6}{|c|}{ Genotype } & \multirow[b]{3}{*}{$\chi^{2 \mathrm{a}}$} & \multirow[b]{3}{*}{ P-value } \\
\hline & & \multicolumn{2}{|c|}{$\mathrm{CC}$} & \multicolumn{2}{|c|}{$\mathrm{CT}$} & \multicolumn{2}{|c|}{$\mathrm{TT}$} & & \\
\hline & & $\mathrm{n}$ & $\%$ & $\mathrm{n}$ & $\%$ & $\mathrm{n}$ & $\%$ & & \\
\hline Joint & 64 & 55 & 85.94 & 8 & 12.50 & 1 & 1.56 & 0.038 & 0.846 \\
\hline Gastrointestinal tract & 77 & 69 & 89.61 & 8 & 10.39 & 0 & 0.00 & 0.283 & 0.594 \\
\hline Kidney & 80 & 60 & 75.00 & 20 & 25.00 & 0 & 0.00 & 4.257 & 0.039 \\
\hline Control & 100 & 87 & 87.00 & 12 & 12.00 & 1 & 1.00 & & \\
\hline
\end{tabular}

${ }^{a}$ Compared with the overall HSP (HSP with and without nephritis). HSP, Henoch-Schönlein purpura.

Table VII. Correlation between the paired box 2 gene polymorphism 798C $>\mathrm{T}$ in exon 8 and the clinical characteristics and pathological lesions of children with Henoch-Schönlein purpura with nephritis.

\begin{tabular}{|c|c|c|c|c|c|c|c|}
\hline \multirow[b]{3}{*}{ Kidney lesion } & \multirow[b]{3}{*}{ Number, $\mathrm{n}$} & \multicolumn{4}{|c|}{ Genotype } & \multirow[b]{3}{*}{$\chi^{2 a}$} & \multirow[b]{3}{*}{ P-value ${ }^{a}$} \\
\hline & & \multicolumn{2}{|c|}{$\mathrm{CC}$} & \multicolumn{2}{|c|}{$\mathrm{CT}$} & & \\
\hline & & $\mathrm{n}$ & $\%$ & $\mathrm{n}$ & $\%$ & & \\
\hline Patient numbers & 80 & 60 & 75.00 & 20 & 25.00 & & \\
\hline Microscopic hematuria & 58 & 42 & 72.41 & 16 & 27.59 & 0.117 & 0.773 \\
\hline Gross hematuria & 72 & 55 & 76.39 & 17 & 23.61 & 0.040 & 0.842 \\
\hline Small quantity of proteinuria & 34 & 26 & 76.47 & 8 & 23.53 & 0.028 & 0.827 \\
\hline Large quantity of proteinuria & 17 & 10 & 58.80 & 7 & 41.20 & 1.826 & 0.177 \\
\hline Hypertension & 37 & 30 & 81.10 & 7 & 18.90 & 0.567 & 0.468 \\
\hline Nephrotic syndrome & 12 & 7 & 58.30 & 5 & 41.70 & 1.465 & 0.226 \\
\hline Nephritis syndrome & 44 & 35 & 79.60 & 9 & 20.40 & 0.327 & 0.567 \\
\hline
\end{tabular}

${ }^{\mathrm{a} C o m p a r e d ~ w i t h ~ o v e r a l l ~ H S P ~(H S P ~ w i t h ~ a n d ~ w i t h o u t ~ n e p h r i t i s) . ~ H S P, ~ H e n o c h-S c h o ̈ n l e i n ~ p u r p u r a . ~}$

No studies were available on the association between the PAX2 haplotype 798C $>$ T/909 A $>C$ and SNP 1164T $>$ A with the susceptibility and clinical pathophysiological characteristics of HSP. To the best of our knowledge, this is the first study to identify a low frequency SNP of exon $11(1164 \mathrm{~T}>\mathrm{A})$ in the PAX2 gene in Han children. In addition, the 798C $>$ T/909A $>C$ PAX2 genotype did not increase the susceptibility to HSP, but it was likely to increase the susceptibility of kidney involvement. Therefore, this finding may be significant in the diagnosis of HSPN.

In all 218 subjects, the exons 1-7, 9, 10 and 12 of PAX2 demonstrated a single peak, indicating no mutation. This result was inconsistent with those of Gelb et al, in which SNPs, including $291 \mathrm{C}>\mathrm{T}$ at exon 3 and $932 \mathrm{C}>\mathrm{T}$ at exon 9 , were identified (22). This may be due to geographic and ethnic differences. In the present study, two SNPs of the PAX2 gene were identified in exon 8 as a complete linkage haplotype $798 \mathrm{C}>\mathrm{T} / 909 \mathrm{~A}>\mathrm{C}$. The frequency of the allele $798 \mathrm{~T}$ and $909 \mathrm{C}$ was $7 \%$ in the control group. However, the study by Shim et al demonstrated allelic exchange of the PAX2 gene and no linkage haplotype in American children (33). The difference from the results of the present study may also be explained by ethnic differences. A T $>$ A polymorphism at exon 11 was first reported with a frequency of $0.5 \%$. In the version of NM003988, a mutated allele 1164A (Leu388->Leu388) was reported in the present study. No significant differences were identified in this genotype frequency distribution between patients with HSP and the control group, suggesting that the PAX2 gene polymorphism had no correlation with the susceptibility to, or pathophysiological characteristics of HSP. However, the detailed mechanism underlying this may be revealed by further studies.

No significant difference was identified in the frequency of allele 798C/909A between the HSP and the control groups $(\mathrm{P}>0.05)$, nor in the joint or gastrointestinal organ damage groups $(\mathrm{P}>0.05)$. However, the frequency of genotype 798CT/909AC in the HSPN group was significantly higher than that in the control or the HSP without nephritis group $(\mathrm{P}<0.05)$. These data indicated that the PAX2 gene polymorphism neither predisposed individuals to develop HSP, nor to develop joint and gastrointestinal tract symptoms in HSP, although the PAX2 gene polymorphism may be associated with the development of kidney lesions in HSP. 
Although no difference was identified in the disruption of haplotype 798C 909A and 798T 909C in the PAX2 gene between the HSP and the control group, the frequency of the genotype $798 \mathrm{C}>\mathrm{T}$ in the HSPN group was significantly higher than that in the control group $(\mathrm{P}=0.039)$. However, no significant difference in frequency was demonstrated between the HSP and the control groups. These results indicated that the risk for HSP was not increased in children with genotype 798C $>$ T/909A $>C$, however, it may increase susceptibility to the development of kidney lesions in children with HSP. Ballinger et al identified that $97 \%$ of children with HSP demonstrate kidney lesions within 3 months (34). As the follow-up of all subjects in the present study lasted $>6$ months, the SNP results may be valuable in determining the susceptibility to the development of kidney lesions in children with HSP.

The study by Yi et al reported that the $1410 \mathrm{C}>\mathrm{T} / 1521 \mathrm{~A}>\mathrm{C}$ genotype in PAX2 may predispose to kidney damage in Chinese children with HSP (27). Kidney damage in HSPN patients is characterized by hematuria, proteinuria, hypertension, nephrotic syndrome or nephritic syndrome. Although differences were identified in the distribution of the PAX2 polymorphism among the clinical phenotypes, they were statistically insignificant. This suggested there was no correlation between genotype and the various clinical manifestations of HSPN or the progression or prognosis of renal pathology. A larger study population is required in future studies.

In conclusion, the present study identified a polymorphism of exon 11 in the PAX2 gene (1164T>A mutation). Geographic and ethnic disparities may have caused different PAX2 gene polymorphisms. The PAX2 heterozygous genotype 798C $>\mathrm{T}$ does not increase susceptibility to HSP, but it can be used clinically as a HSP screening indicator in children with a high risk of renal involvement.

\section{References}

1. Li L, Zhang J, Zhang Y and Ji H: Thrombosis warning in children suffering from henoch-schonlein purpura. Indian J Dermatol 58: 409, 2013.

2. Chen O,Zhu XB, Ren P, Wang YB, Sun RP and Wei DE: Henoch Schonlein Purpura in children: clinical analysis of 120 cases. Afr Health Sci 13: 94-99, 2013.

3. Zaid M, Tan K, Smitasin N, Tambyah PA and Archuleta S: Henoch-Schönlein purpura associated with adult human immunodeficiency virus infection: case report and review of the literature. Ann Acad Med Singapore 42: 358-360, 2013.

4. Wang HL, Liu HT, Chen Q, Gao Y and Yu KJ: Henoch-Schonlein purpura with intestinal perforation and cerebral hemorrhage: a case report. World J Gastroenterol 19: 2574-2577, 2013.

5. Ghosh K, Chatterjee A, Sau JT and Dey S: Stroke and skin rash: A rare case of Henoch-Schonlein purpura. Ann Indian Acad Neurol 15: 307-309, 2012

6. Fukushima K: Severe intestinal lesions and neuropathy associated with Henoch-Schonlein purpura. Intern Med 52: 2009-2010, 2013

7. Ren X, Zhang W, Dang W, et al: A case of anaphylactoid purpura nephritis accompanied by pulmonary hemorrhage and review of the literature. Exp Ther Med 5: 1385-1388, 2013.

8. Kawasaki Y, Ono A, Ohara S, et al: Henoch-Schonlein purpura nephritis in childhood: pathogenesis, prognostic factors and treatment. Fukushima J Med Sci 59: 15-26, 2013.

9. An J, Lu Q, Zhao H, Cao Y, Yan B and Ma Z: A study on the association between C1GALT1 polymorphisms and the risk of Henoch-Schonlein purpura in a Chinese population. Rheumatol Int 33: 2539-2542, 2013.

10. Wang JJ, Shi YP, Huang Y, Wu C and Li XC: Association of tumor necrosis factor-alpha gene polymorphisms with Henoch-Schonlein purpura nephritis in children. Zhongguo Dang Dai Er Ke Za Zhi 15: 88-90, 2013 (In Chinese).
11. Wang JJ, Shi YP, Yue H, Chun W and Zou LP: CTLA-4 exon 1 $+49 \mathrm{~A} / \mathrm{G}$ polymorphism is associated with renal involvement in pediatric Henoch-Schönlein purpura. Pediatr Nephrol 27: 2059-2064, 2012

12. Tabel Y, Mir S and Berdeli A: Interleukin 8 gene 2767 A/G polymorphism is associated with increased risk of nephritis in children with Henoch-Schönlein purpura. Rheumatol Int 32: 941-947, 2012.

13. Ren SM, Yang GL, Liu CZ, et al: Association between HLA-A and -B polymorphisms and susceptibility to Henoch-Schönlein purpura in Han and Mongolian children from Inner Mongolia. Genet Mol Res 11: 221-228, 2012.

14. He X, Lu H, Kang S, et al: MEFV E148Q polymorphism is associated with Henoch-Schönlein purpura in Chinese children. Pediatr Nephrol 25: 2077-2082, 2010.

15. Li J and Liu H: P-selectin gene -825 polymorphism is associated with risk of Henoch-Schonlein purpura nephritis. Clin Exp Rheumatol 29: S134, 2011.

16. Soylu A, Kizildağ S, Kavukçu S, et al: TLR-2 Arg753Gln, TLR-4 Asp299Gly, and TLR-4 Thr399Ile polymorphisms in Henoch Schonlein purpura with and without renal involvement. Rheumatol Int 30: 667-670, 2010.

17. Nalbantoglu S, Tabel Y, Mir S and Berdeli A: Lack of association between macrophage migration inhibitory factor gene promoter $(-173 \mathrm{G} / \mathrm{C})$ polymorphism and childhood Henoch-Schönlein purpura in Turkish patients. Cytokine 62: 160-164, 2013.

18. He X, Li Y, Kang S, et al: The CD18 AvaII polymorphic site not associated with Henoch-Schönlein purpura. Clin Exp Rheumatol 29: S117-S120, 2011.

19. Torres O, Palomino-Morales R, Miranda-Filloy JA, Vazquez-Rodriguez TR, Martin J and Gonzalez-Gay MA: Lack of association between toll-like receptor 4 gene polymorphism and Henoch-Schönlein purpura. Clin Exp Rheumatol 28: 110, 2010.

20. López-Mejías R, Sevilla Pérez B, Genre F, et al: No evidence of association between functional polymorphisms located within IL6R and IL6ST genes and Henoch-Schönlein purpura. Tissue Antigens 82: 416-419, 2013

21. Torban E, Eccles MR, Favor J and Goodyer PR: PAX2 suppresses apoptosis in renal collecting duct cells. Am J Pathol 157: 833-842, 2000.

22. Gelb A, Manligas G, Gharaybeh S and Schimmenti L: Identification of two novel polymorphisms (g.903C $>\mathrm{T}$ and g.1544C >T) in the PAX2 gene. Hum Mutat 17: 155, 2001.

23. Harshman LA and Brophy PD: PAX2 in human kidney malformations and disease. Pediatr Nephrol 27: 1265-1275, 2012.

24. Porteous S, Torban E, Cho NP, et al: Primary renal hypoplasia in humans and mice with PAX2 mutations: evidence of increased apoptosis in fetal kidneys of Pax 2(1Neu) +/- mutant mice. Hum Mol Genet 9: 1-11, 2000.

25. Thomas R, Sanna-Cherchi S, et al: HNF1B and PAX2 mutations are a common cause of renal hypodysplasia in the CKiD cohort. Pediatr Nephrol 6: 897-903, 2011.

26. Zu CP, Yi ZW and Dang XQ: Significance of PAX2 expression in pathological kidney of children with Henoch-Schoenlein purpura nephritis. Journal of Clinical Research 22: 1514-1517, 2005.

27. Yi ZW, Fang XL, Wu XC, et al: Role of PAX2 gene polymorphisms in Henoch-Schonlein purpura nephritis. Nephrology (Carlton) 11: 42-48, 2006.

28. Loghman-Adham M: Evaluating proteinuria in children. Am Fam Physician 58: 1145-1152, 1158-1149, 1998.

29. No authors listed: Primary nephrotic syndrome in children: clinical significance of histopathologic variants of minimal change and of diffuse mesangial hypercellularity. A Report of the International Study of Kidney Disease in Children. Kidney Int 20: 765-771, 1981.

30. Miller SA, Dykes DD and Polesky HF: A simple salting out procedure for extracting DNA from human nucleated cells. Nucleic Acids Res 16: 1215, 1988

31. Tellier AL, Amiel J, Delezoide AL, et al: Expression of the PAX2 gene in human embryos and exclusion in the CHARGE syndrome. Am J Med Genet 93: 85-88, 2000.

32. Schimmenti LA, Cunliffe HE, McNoe LA, et al: Further delineation of renal-coloboma syndrome in patients with extreme variability of phenotype and identical PAX2 mutations. Am J Hum Genet 60: 869-878, 1997.

33. Shim HH, Nakamura BN, Cantor RM and Schimmenti LA: Identification of two single nucleotide polymorphisms in exon 8 of PAX2. Mol Genet Metab 68: 507-510, 1999.

34. Ballinger S: Henoch-Schonlein purpura. Curr Opin Rheumatol 5: 591-594, 2003. 